\title{
International Journal of STEM Education - a platform to promote STEM education and research worldwide
}

\author{
Yeping Li
}

The International Journal of STEM Education is an online open-access journal that focuses on the study of learning and teaching in science, technology, engineering, and mathematics (STEM). It is being established as a brand new, forward looking journal that will add the multidisciplinary perspectives needed to complement current disciplinary-focused journals in the field of STEM education. As a peer-reviewed journal, it is positioned to promote original, systematic, and high-quality research and program development in the rapidly evolving, multidisciplinary, and global field of STEM education.

The emerging field of STEM education presents a fascinating opportunity. At the policy level, providing high-quality STEM education has been recognized as critical for a nation's prosperity and security around the world, including developing as well as developed countries. For example, US President Obama's Reform for the Future agenda (see http://www.whitehouse.gov/ issues/education/reform) highlights the needs for (1) Race to the Top, (2) redesigning and reforming No Child Left Behind, (3) fortifying science, technology, engineering and math (STEM) education, (4) sparking innovation, (5) ensuring opportunity for all, and (6) strengthening the teaching profession. Strengthening STEM education is clearly taken as a priority. Similar national agendas can be found in many other countries. The commitment to promote and improve STEM education goes well beyond words, as evidenced by consistent and strong funding support. In the USA, the federal government spends nearly $\$ 3$ billion on STEM education programs annually. Private funding also supports STEM education with an additional US $\$ 1$ billion each year. The ever-increasing interests and research are also evidenced in the active development of numerous professional organizations and conferences related to STEM education. However, scholarly publication venues in the field of STEM education are limited,

Correspondence: yepingli@tamu.edu

Texas A\&M University, College Station, TX 77843, USA suggesting that scholarly development of STEM education is in its early stages.

In academic fields, educational researchers in various STEM disciplines have typically pursued work from their unique vantage point over the past decades. Now is the time to offer a journal that emphasizes STEM educational issues that span disciplinary boundaries. Widely accessible journals can significantly influence research and program development, inform educators and policy makers around the world, and catalyze new areas of research. The International Journal of STEM Education is thus established to promote research on STEM education and advance the field of STEM education by (1) providing an outlet to publish and share research from various disciplines and methods, (2) increasing access to research findings for researchers and educators through the journal's open-access platform, and (3) galvanizing scientists and educational researchers to further our knowledge about STEM education.

The journal is open to all issues in STEM education across all levels from pre-college through continuing education while focusing on the study of the process of STEM learning and teaching. It provides a unique platform for sharing research regarding, among other things, the design and practices of technology-rich learning environments, innovative pedagogies, teacher development, and curricula in STEM education that promote successful learning and teaching. We are also interested in studies that address specific challenges in improving students' achievement in STEM, specific approaches used to motivate and engage students in STEM learning, and lessons learned from changes in curriculum and instruction in STEM.

The journal publishes a broad array of articles including original research, research reviews, short reports, and commentaries. In particular, the journal values unique contributions from different perspectives that view STEM education either as traditionally defined subject-based education or as an educational undertaking in interconnected STEM fields. 
There are no methodological restrictions, but this journal aims to foster multidisciplinary research and development through contributions that are empirically grounded and blend subject content expertise and educational research. Contributions are encouraged from scholars within and across subject content fields (e.g., science, technology, engineering, and mathematics) and social science fields (e.g., education, psychology, and sociology) to promote scholarly exchange and discussion on emerging issues and frontier research in STEM education. In addition, the journal also publishes special issues that have specific focuses or themes. Special issues can be guest-edited, and researchers are encouraged to submit special issue proposals with a focus or theme that is of great interest in the community of STEM educators and policy makers.

The journal accepts and reviews manuscripts through an online manuscript processing system. Interested contributors can obtain detailed instruction online at http://www.stemeducationjournal.com/authors/instructions. For editorial inquiries, please email the journal at editorial@stemeducationjournal.com. For technical support, please contact SpringerOpen at info@springeropen.com. Each submitted manuscript will be processed by the journal's editorial office first. After passing the initial screen, each manuscript will be reviewed by two or more experts using a double-blind peer review system. All manuscripts will be processed and reviewed in a timely fashion in order to provide a fast publication schedule while maintaining rigorous peer review.

The advantages of publishing with us include the following:

- Quick turn-around times for publication

- Rigorous peer and editorial review

- High visibility and unrestricted online access to your work

- Increased probability of prompt citations

- Citation tracking and inclusion in bibliographic databases

- Unlimited space for supplementary material

- Retention of copyright

- Easy compliance with open-access mandates

The International Journal of STEM Education is abstracted/indexed in Google Scholar, OCLC, PsycINFO, Scopus, and Summon by Serial Solutions. The journal will also be indexed in Web of Science as soon as possible.

Received: 8 July 2014 Accepted: 13 July 2014

Published: 27 August 2014

doi:10.1186/2196-7822-1-1

Cite this article as: Li: International Journal of STEM Education - a platform

to promote STEM education and research worldwide. International Journal of STEM Education 2014 1:1.
Submit your manuscript to a SpringerOpen ${ }^{\circ}$ journal and benefit from:

- Convenient online submission

- Rigorous peer review

- Immediate publication on acceptance

- Open access: articles freely available online

- High visibility within the field

- Retaining the copyright to your article

Submit your next manuscript at $>$ springeropen.com 